\title{
Inactivation of Bacterial Wilt in Closed Soilless Cultivation by Photocatalytic Treatment and Silver
}

\author{
Yoko Miyama ${ }^{1}$, Yoko Kawashima ${ }^{1}$, Junko Ogawa ${ }^{1}$, Hidetoshi Uekusa ${ }^{1}$, Tamotsu Oкамото ${ }^{1}$, Nobuhiro Kita ${ }^{1}$, \\ Kayano SUNADA ${ }^{2}$ and Kazuhito HASHIMOTO ${ }^{2,3}$ \\ ' Kanagawa Agricultural Technology Center, 1617 Kamikisawa, Hiratsuka, Kanagawa 259-1204, Japan \\ ${ }^{2}$ Research Center for Advanced Science and Technology, The University of Tokyo, 4-6-1 Komaba, Meguro-ku, Tokyo 153-8904, Japan \\ ${ }^{3}$ Department of Applied Chemistry, Faculty of Engineering, The University of Tokyo, 7-3-1 Hongo, Bunkyo-ku, Tokyo 113-8656, Japan
}

(Received August 5, 2013; Accepted September 27, 2013)

\begin{abstract}
From the viewpoint of conservation-oriented agriculture, a closed soilless cultivation using an organic substrate is desirable. We found that photocatalytic treatment efficiently decomposed phytotoxic compounds from rice hull, and the growth and yield of tomatoes in a closed system with the treatment were superior to a system without it. To enhance disease control in the system, this study investigated the suppression of bacterial wilt disease in a simulated waste nutrient solution with photocatalytic and silver treatments. The untreated waste nutrient solution had a high total organic carbon (TOC) concentration, and silver in the untreated solution had no antibacterial activity. By contrast, silver in the photocatalytically treated solution showed a high antibacterial effect via the low TOC of the treated solution. A similar trend of disease onset was observed when pathogenic bacteria were inoculated into the solutions used to cultivate tomato seedlings. These results suggest that, even if the concentration of organic species in waste nutrient solution from a closed system is high, lowering the TOC by photocatalytic treatment promotes the suppression of bacterial wilt disease through the antibacterial activity of silver. It is anticipated that combining photocatalytic and silver treatments will help to stabilize crop production in closed soilless cultivation.
\end{abstract}

Keywords : antibacterial effect, bacterial wilt disease, closed soilless cultivation, silver, $\mathrm{TiO}_{2}$ photocatalysis, tomato

\section{INTRODUCTION}

From the viewpoint of environmental conservation agriculture, it is desirable not only to switch nutrient solutions from opened to closed systems in soilless cultivation, but also to switch culture substrates from rockwool to organic substrates, such as rice hull or coconut husk (Van Os, 1994, 1995, 2000; Shinohara et al., 1999; Urrestarazu et al., 2005). The switching to the closed system prevents groundwater and river from an eutrophication, and another switching to organic substrates do not emit used rockwools as industrial wastes, furthermore, organic substrates can easily return to the fields.

$\mathrm{TiO}_{2}$ is a photocatalytic compound that has a strong oxidizing effect upon irradiation with ultraviolet (UV) light and can convert various types of organic compounds into carbon dioxide by oxidative decomposition (Hoffmann et al., 1995; Fujishima et al., 1999; Herrmann, 1999; Hashimoto et al., 2005). Numerous researchers have attempted to exploit this photocatalytic reaction to decompose environmental pollutants in air and water (Ollis et al., 1991; Noguchi et al., 2003; Pichat et al., 2005). In our previous study, we have confirmed that phytotoxic compounds from rice hulls substrate in waste nutrient solution are decomposed and detoxified through the treatment system with $\mathrm{TiO}_{2}$ under solar light irradiation (Sunada et al., 2008;
Miyama et al., 2009; 2012). Furthermore, the growth and yield of tomatoes in a closed cultivation with the treatment system were significantly higher than those with untreated system. It is well known that $\mathrm{TiO}_{2}$ photocatalysts have antibacterial activity (Sunada et al., 2003), however, we had no observation of disease suppression in the closed tomatoes cultivation system with photocatalytic treatment.

Soil-borne diseases can occur even in soilless cultivation systems (Zinnen, 1988). For example, the soil bacterium Ralstonia solanacearum, which causes wilt disease in tomatoes, can be introduced into soilless cultivation fields by carrier seedlings, aerosols, or dust (Hayward, 1991; Stanghellini and Rasmussen, 1994). As this bacterium multiplies in the rhizosphere and invades the roots of tomato plants (Jenkins and Averre, 1983), wilt disease occurs and rapidly spreads over entire closed soilless systems, causing serious damage and yield loss. Therefore, it is necessary to develop effective methods for preventing the infestation of crop plants in soilless cultivation beds.

Silver ions are well known to possess antibacterial properties. Silver-coated cloth, which consists of $100 \%$ nylon fibers whose surfaces are uniformly loaded with fine particles of silver by electroless plating, is presently the only commercially available pesticide that can legally be added to nutrient solutions used for soilless cultivation in Japan. When silver-coated cloth is placed into a nutrient solution tank, silver ions are eluted and diffuse throughout

Corresponding author: Kayano Sunada, fax: +81-3-5452-5084, e-mail : kayano@light.t.u-tokyo.ac.jp 
(a)

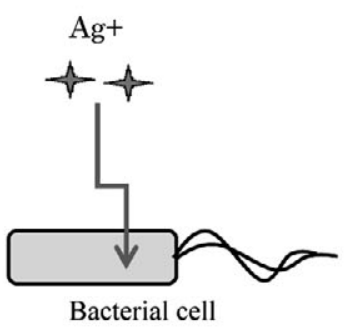

$\mathrm{Ag}^{+}$shows antibacterial effect in nutrient solution containing low concentration of TOC.

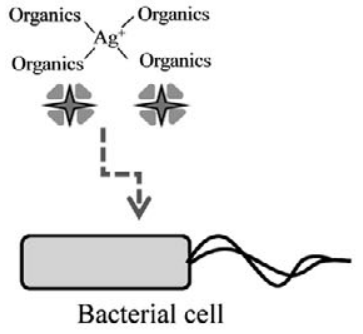

$\mathrm{Ag}^{+}$shows weak antibacterial effect in nutrient solution containing high concentration of TOC.

(b)

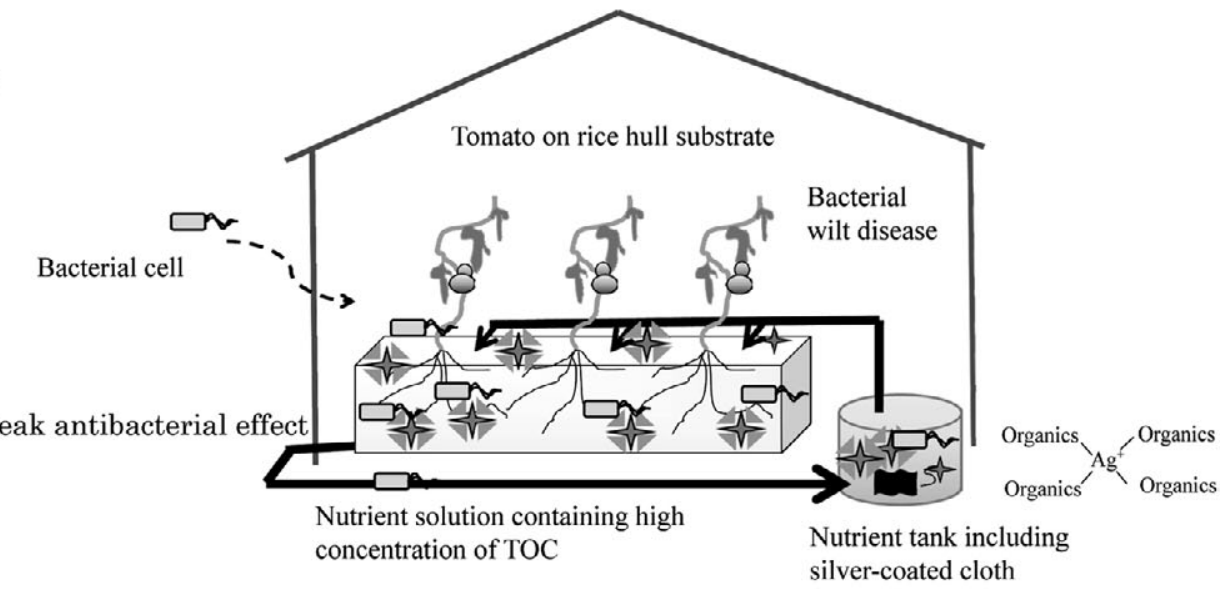

(c)

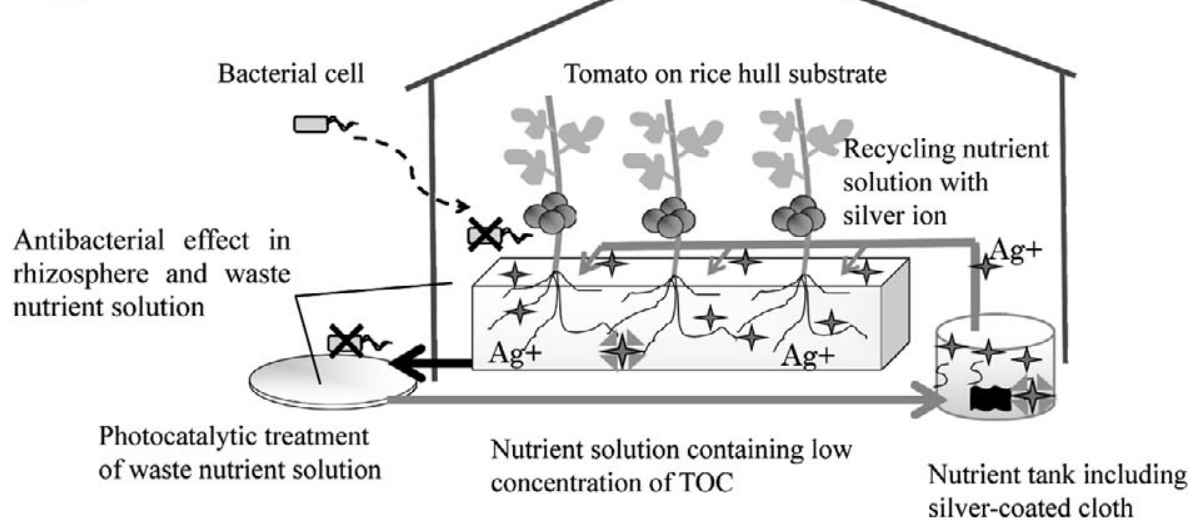

Fig. 1 Schematic diagram of (a) silver forms with and without organics, and (b) untreated and (c) photocatalytically treated closed soilless cultivation systems, using rice hull substrate and silver-coated cloth in an actual greenhouse.

the solution, providing an antibacterial effect on even the roots of crops cultivated in soilless beds (Kusakari et al., 1998; Zhao et al., 2000). However, the waste nutrient solution in closed soilless cultivation contains high concentrations of organic contaminants released from organic substrate materials and the crop itself (Sunada et al., 2008; Miyama et al., 2009). In particular, high concentrations of organic contaminants are extracted from organic substrates such as rice hull and coconut husk. It is thought that the antibacterial effects of silver ions decrease in the presence of organic contaminants in waste nutrient solution (Fig. 1(a)). As antibacterial activity typically involves the denaturation of functional biomolecules, which include enzymes and nucleic acids, resulting from their binding to silver ions (Thurman and Gerba, 1989), competitive organic contaminants present in nutrient solutions cause a potential reduction of the effects of silver. Therefore, it is likely to be difficult for silver ions, originating from silvercoated cloth, to exert antibacterial activity against pathogenic bacteria on plant roots in closed soilless cultivation systems (Fig. 1(b)). To obtain the antibacterial effect of silver ions, it is necessary to decrease the concentration of organic contaminants in the waste nutrient solution. In other words, if photocatalytic treatment decomposes the organic contaminants, silver ions in the waste nutrient solution could have antibacterial effect even in the closed system 
(Fig. 1(c)).

The purpose of this study is to examine the effectiveness of photocatalytically treated nutrient solutions containing silver ions to maximize their antibacterial activity in a closed soilless cultivation system using a rice hull substrate. The relationship between the concentration of total organic carbon (TOC) and the antibacterial effects of silver ions was investigated by immersing silver nitrate in pure, untreated, and photocatalytically treated nutrient solutions. To evaluate the disease protection ability of silver ions in the three nutrient solutions, these were used to cultivate tomato seedlings inoculated with $R$. solanacearum; disease severity and bacterial numbers were measured.

\section{MATERIALS AND METHODS}

\section{Preparation of test solutions}

Three test solutions were prepared by adding nutrients (Otsuka-A formula, 0.5 units) to deionized water (pure nutrient solution), rice hull extract (untreated nutrient solution), or photocatalytically treated rice hull extract (photocatalytically treated nutrient solution), respectively. Rice hull extract was prepared by washing rice hulls twice with deionized water $\left(100 \mathrm{~g}\right.$ rice hulls $\left.\mathrm{L}^{-1}\right)$. After adding a further $1 \mathrm{~L}$ deionized water, the rice hulls were allowed to soak at $35^{\circ} \mathrm{C}$ for $16 \mathrm{~h}$, and were then removed by filtration through a $6 \mu \mathrm{m}$ filter. To prepare the photocatalytically treated nutrient solution, $0.1 \mathrm{~g} \mathrm{~L}^{-1} \mathrm{TiO}_{2}$ powder (P-25, Nippon Aerosil Co., Ltd., Japan) was added to a portion of the rice hull extract solution, which was then placed in a $1 \mathrm{~L}$ petri dish and irradiated with a blacklight $(3.0 \mathrm{~mW}$ $\mathrm{cm}^{-2}$ ) for 2 weeks. After adding nutrients to each of the three test solutions, the $\mathrm{pH}$ was adjusted to 6.5 by adding either phosphoric acid or potassium hydroxide, as appropriate. Inorganic nutrients in three test solutions were almost the same concentrations (data not shown).

Silver-coated cloth

Silver-coated cloth (Satosen Co., Ltd., Japan) was used in the experiments. Silver-coated cloth pellets $(1 \times 1.5$ $\mathrm{cm})$ were placed into $500 \mathrm{~mL}$ of each test solution. The resulting mixtures were stored at $20^{\circ} \mathrm{C}$ for a specified period and samples periodically collected to measure the silver concentration. In this paper, we use the term 'silver' to indicate silver ions or silver ions bound to organics (Fig. $1(\mathrm{a})$.

\section{Determination of silver and TOC concentration}

The concentration of silver, in the form of silver ions, organosilver complexes, etc. (Fig. 1(a)), in the nutrient solutions was determined using an HP 4500 inductively coupled plasma mass spectrometry (ICP-MS) system (Yokogawa Analytical Systems Inc., Japan). Palladium (10 $\mu \mathrm{g} \mathrm{L}^{-1}$ ) was used as an internal standard of mass number 105 , and an integration time of $0.1 \mathrm{~s}$ (performed 5 times) was used for all measurements.

The concentration of TOC in test solutions was determined using a TOC-5000A analyzer (Shimadzu Co., Japan).
Evaluation of the antibacterial effect of eluted silver against $R$. solanacearum

$R$. solanacearum (strain KNOB53) was cultured in nutrient agar medium at $28^{\circ} \mathrm{C}$ and then suspended in sterilized water at a concentration of $3.5 \times 10^{9}$ colony forming units (cfu) $\mathrm{m} \mathrm{L}^{-1}$ as an inoculum for challenge experiments. Bacterial suspension $(2 \mathrm{~mL}$ ) was added to each test solution $(18 \mathrm{~mL})$ after addition of $42 \mu \mathrm{g} \mathrm{L}^{-1}$ silver nitrate $\left(\mathrm{AgNO}_{3}\right)$, and the resulting suspensions were incubated for $24 \mathrm{~h}$ at $25^{\circ} \mathrm{C}$. The number of bacteria in the suspensions was determined at scheduled times by counting colonies on a nutrient agar medium plate incubated for 3 days at $28^{\circ} \mathrm{C}$.

Measurement of wilt disease severity in tomato seedlings

An aqueous solution of $\mathrm{AgNO}_{3}$ was added to the test nutrient solutions, at a silver concentration of $40 \mu \mathrm{g} \mathrm{L}^{-1}$, and stirred overnight at room temperature. Bacterial suspension $\left(20 \mathrm{~mL}, 2.0 \times 10^{8} \mathrm{cfu} \mathrm{mL}^{-1}\right)$ was added to the test solutions $(1,500 \mathrm{~mL})$, and then stirred for an additional $3 \mathrm{~h}$. $70 \mathrm{~mL}$ of each solution was added to separate $100 \mathrm{~mL}$ beakers. Two weeks old tomato seedlings (Lycopersicon esculentum Mill. cv. Hausu-Momotaro; Takii Seed Co., Ltd., Japan), grown in an artificially controlled environment were placed into each solution after cutting the roots in half lengthwise in order to facilitate the infection of pathogen (Ohata et al., 1995). The onset of wilt disease was evaluated after cultivating the seedlings in an artificially controlled environment for 1 week. The extent of disease was classified as "healthy" $=0$, "etiolated" $=1$, "wilted" $=2$, or "dead" $=3$.

\section{RESULTS}

When silver-coated cloth was added to nutrient solution, a target silver concentration of $40 \mu \mathrm{g} \mathrm{L}^{-1}$, which is effective against plant pathogenic bacteria without damaging crop roots, was set (Slade and Pegg, 1993; Kusakari et al., 1998). Here, silver was eluted similarly from the silvercoated cloth in both the untreated and photocatalytically treated nutrient solutions (Table 1). The concentration of silver reached $40 \mu \mathrm{g} \mathrm{L}^{-1}$ in less than 4 days after adding the cloth to the solutions. In the following experiments, $\mathrm{AgNO}_{3}$ was used as the silver source instead of silvercoated cloth to obtain the constant concentration of silver in test solutions.

Next, the antibacterial activity of silver against $R$. solanacearum was evaluated as evidenced by temporal change of bacterial concentration (Table 2). In pure nutrient solution ( $\mathrm{TOC}=5 \mathrm{mg} \mathrm{L}^{-1}$ ) supplemented with silver, the concentration of bacteria decreased from an initial concentration of $3.5 \times 10^{8} \mathrm{cfu} \mathrm{mL}^{-1}$ to $1.9 \times 10^{4} \mathrm{cfu} \mathrm{mL}^{-1}$ after $1 \mathrm{~h}$, representing an approximately $4.3 \log$ decline, and levels were below the detection limit after $3 \mathrm{~h}$. Conversely, in the untreated solution ( $\mathrm{TOC}=174 \mathrm{mg} \mathrm{L}^{-1}$ ), the concentration of bacteria slowly decreased, only reaching an approximately $0.9 \log$ reduction in cfu $\mathrm{mL}^{-1}$ after $1 \mathrm{~h}$, and a $1.2 \mathrm{log}$ decline after $6 \mathrm{~h}$. By contrast, in the photocatalytically treated solution $\left(\mathrm{TOC}=14 \mathrm{mg} \mathrm{L}^{-1}\right.$ ), the bacterial concentration displayed a $4.6 \mathrm{log}$ decline from the starting value 
Table 1 Silver concentration in untreated and photocatalytically treated rice hull extracts containing nutrients after the addition of silver-coated cloth.

\begin{tabular}{lrcccc}
\hline \multirow{2}{*}{ Test nutrient solution } & \multirow{2}{*}{ TOC $\left(\mathrm{mg} \mathrm{L}^{-1}\right)$} & \multicolumn{4}{c}{ Silver concentration $\left(\mu \mathrm{g} \mathrm{L}^{-1}\right)$} \\
\cline { 3 - 6 } & & 0 day & 1 day & 2 day & 4 day \\
\hline Untreated & $174 \pm 1.2$ & 0 & 19 & 27 & 55 \\
Photocatalytically treated & $14 \pm 0.6$ & 0 & 15 & 32 & 60 \\
\hline TOC; total organic carbon. & & & & &
\end{tabular}

Table 2 Concentration of $R$. solanacearum in photocatalytically treated and untreated solutions and pure nutrient solutions with and without silver ${ }^{2}$.

\begin{tabular}{|c|c|c|c|c|c|}
\hline \multirow{2}{*}{ Test nutrient solution } & \multirow{2}{*}{$\frac{\text { TOC }}{\left(\mathrm{mg} \mathrm{L}^{-1}\right)}$} & \multicolumn{4}{|c|}{ Concentration of $R$. solanacearum $\left(\mathrm{cfu} \mathrm{mL}^{-1}\right)^{y}$} \\
\hline & & $1 \mathrm{~h}$ & $3 \mathrm{~h}$ & $6 \mathrm{~h}$ & $24 \mathrm{~h}$ \\
\hline Pure nutrient solution without silver & 5 & - & - & - & $1.4 \times 10^{9}$ \\
\hline Pure nutrient solution with silver & 5 & $1.9 \times 10^{4}$ & N.D. & N.D. & N.D. \\
\hline Untreated nutrient solution with silver & 174 & $4.7 \times 10^{7}$ & $1.3 \times 10^{7}$ & $1.8 \times 10^{6}$ & $4.7 \times 10^{3}$ \\
\hline Photocatalytically treated nutrient solution with silver & 14 & $8.4 \times 10^{3}$ & $2.8 \times 10^{2}$ & N.D. & N.D. \\
\hline
\end{tabular}

${ }^{2}$ The silver concentration was $42 \mu \mathrm{g} \mathrm{L}^{-1}$.

${ }^{\mathrm{y}}$ The initial concentration of $R$. solanacearum was $3.5 \times 10^{8} \mathrm{cfu} \mathrm{mL}^{-1}$.

N.D.; non-detectable concentration, - ; no measurement, TOC; total organic carbon.

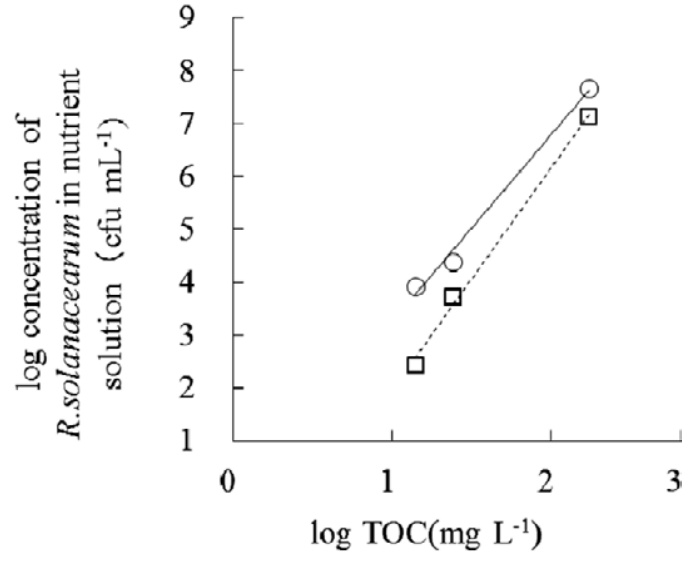

Fig. 2 Relationship between TOC concentration and $R$. solanacearum cells in 3 test nutrient solutions. The nutrient solutions were incubated for $1 \mathrm{~h}(\bigcirc)$ and $3 \mathrm{~h}$ ( $\square$ ) after the addition of $3.5 \times 10^{8} \mathrm{cfu} \mathrm{mL}^{-1} R$. solanacearum. The concentration of silver in the nutrient solutions was $42 \mu \mathrm{g} \mathrm{L}^{-1}$.

and became below the detection limit after $6 \mathrm{~h}$. Thus, silver exhibited antibacterial effects in solutions with 5 and 14 $\mathrm{mg} \mathrm{L}^{-1}$ TOC, but had little effect in the high TOC solution. Figure 2 clearly demonstrates the relationship between TOC and the antibacterial activity of silver.

The severity of disease in tomato seedlings grown in the 3 test solutions containing silver is shown in Table 3 and Fig. 3. When silver was added to the pure nutrient solution, no onset of wilt disease was observed in any of the tomato seedlings during the first week after transplantation; $R$. solanacearum bacteria were also not detected. By contrast, the onset of wilt disease was observed in all seedlings cultivated using the untreated solution, which was similar to the results in pure nutrient solution without added silver, and the number of bacteria increased approximately ten fold from the initial concentration $\left(2.0 \times 10^{6} \mathrm{cfu} \mathrm{mL}^{-1}\right)$. The disease scores for seedlings cultivated using untreated and pure nutrient solutions were $2.0 \pm 1.0$ and $2.9 \pm 0.4$, respectively. For the photocatalytically treated solution, there was no onset of disease in the tomato seedlings in the first week after transplantation, a result that is similar to that for pure nutrient solution containing silver. In addition, a 4.2 log decline of bacteria from the initial concentration was observed.

\section{DISCUSSION}

Based on the data presented in Table 2, the antibacterial effect of silver in pure nutrient solution used for the cultivation of tomato was confirmed. The antibacterial activity against $R$. solanacearum was higher in the pure and photocatalytically treated nutrient solutions than that in the untreated solution, even though the three solutions contained the same concentration of silver $\left(42 \mu \mathrm{g} \mathrm{L}^{-1}\right)$. Notably, the activity was dependent on the TOC of the solutions (Fig. 2). In solutions with low TOC, silver is thought to exist mainly in the form of free silver ions, which are active against bacteria, whereas in the high TOC solution, silver ions form complexes with the organic compounds, and thus have lower antibacterial activity (Fig. 1(a)). It has been reported that silver ions likely interact with thiol groups derived from the amino acid cysteine and the phosphate groups of nucleic acids, resulting in impaired bacterial growth (Russell and Hugo, 1994). As organic contaminants present in the nutrient solution from rice hulls contain constituents possessing thiol and phosphate groups, these compounds are able to bind silver ions, leading to decreased antibacterial activity (Fig. 1(b)). Conversely, we found that photocatalytic treatment using $\mathrm{TiO}_{2}$ powder decomposes the organic contaminants present in the nutrient solution, thereby improving the impaired antibacterial activity of the silver ions (Fig. 1(c)).

As shown in Table 3, the incidence of wilt disease in tomato seedlings was correlated with the number of bacteria detected among the 4 test solutions. Silver clearly suppressed the growth of $R$. solanacearum and the occurrence of wilt disease in the pure and photocatalytically treated nutrient solutions with low TOCs. These findings indicate that the antibacterial activity of silver against soil-borne bacteria around the tomato roots can be enhanced by 
Table 3 Effect of photocatalytic treatment with silver on bacterial wilt incidence and disease index of tomato seedlings, and concentrations of silver and bacterial cells after growth of seedlings for 1 week.

\begin{tabular}{|c|c|c|c|c|c|}
\hline \multirow[b]{2}{*}{ Test nutrient solution } & \multirow[b]{2}{*}{$\begin{array}{c}\mathrm{TOC} \\
\left(\mathrm{mg} \mathrm{L}^{-1}\right)\end{array}$} & \multirow{2}{*}{$\begin{array}{l}\text { Wilt } \\
\text { incidence } \\
(\%)\end{array}$} & \multirow[b]{2}{*}{$\begin{array}{l}\text { Disease } \\
\text { score }^{\mathrm{x}}\end{array}$} & \multicolumn{2}{|c|}{ Concentration of } \\
\hline & & & & $\begin{array}{c}\text { Silver } \\
\left(\mu \mathrm{g} \mathrm{L}^{-1}\right)^{y}\end{array}$ & $\begin{array}{l}\text { R. solanacearum } \\
\left(\mathrm{cfu} \mathrm{mL} \mathrm{mL}^{-1}\right)^{\mathrm{z}}\end{array}$ \\
\hline Pure nutrient solution with silver & 5 & 0 & 0 & 36.4 & N.D. \\
\hline Untreated nutrient solution with silver & 144 & 100 & $2.0 \pm 1.0$ & 35.0 & $6.6 \times 10^{7}$ \\
\hline Photocatalytically treated nutrient solution with silver & 14 & 0 & 0 & 36.8 & $1.9 \times 10^{2}$ \\
\hline
\end{tabular}

${ }^{z}$ The initial silver concentration was $40 \mu \mathrm{g} \mathrm{mL}^{-1}$.

${ }^{y}$ The initial concentration of $R$. solanacearum was $2.0 \times 10^{6} \mathrm{cfu} \mathrm{mL}^{-1}$

${ }^{x}$ Wilt disease was scored as "healthy" $=0$, "etiolated" $=1$, "wilted" $=2$, or "dead" $=3$.

"Wilt incidence $=$ disease seedlings/total seedlings $\times 100(\%)$.

20 seedlings were tested for each solution.

N.D.; non-detectable concentration, TOC; total organic carbon.
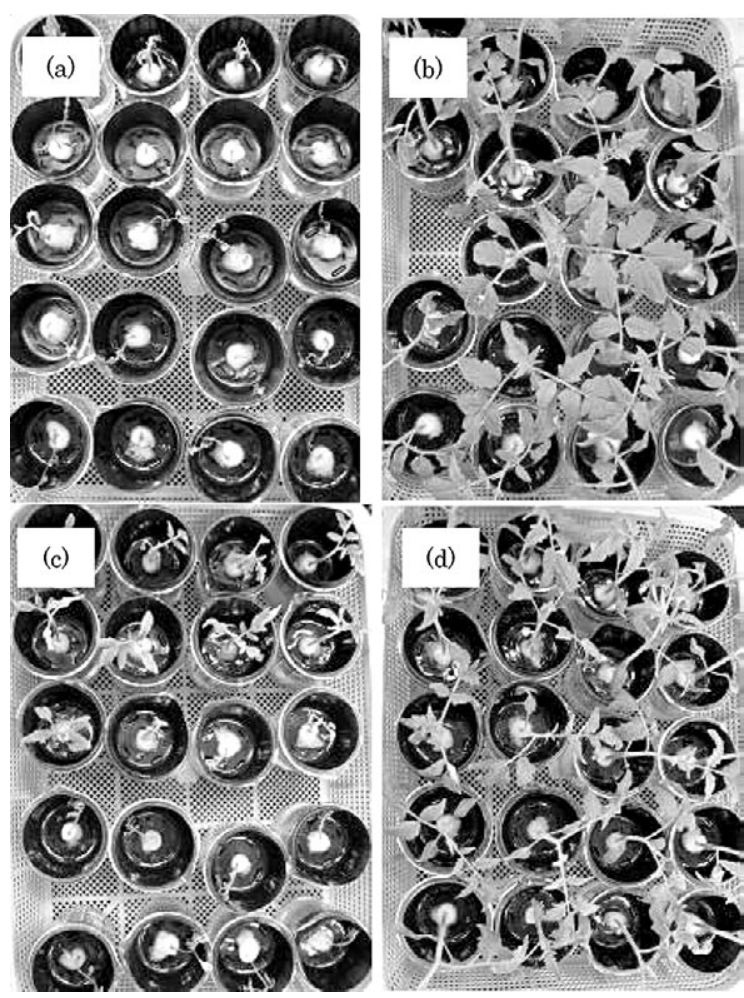

Fig. 3 Photographs of bacterial wilt disease incidence of tomato seedlings in (a) pure nutrient solution without silver, (b) pure nutrient solution with silver, (c) untreated nutrient solution with silver, and (d) photocatalytically treated nutrient solution with silver.

lowering the TOC concentration through photocatalytic treatment. In addition, photocatalytic treatment itself has biocidal activity against microbes (Matsunaga et al, 1985; Sunada et al., 2003). Although $\mathrm{TiO}_{2}$ photocatalytic treatment in our systems has antibacterial effects on bacteria in the nutrient solution, it is not possible to show antibacterial activity in the cultivation substrate or rhizosphere of crop plants in cultivation fields where carrier seedlings, aerosols, or dust have been introduced. By contrast, silver eluted into nutrient solution can kill bacteria near the plant root in such cultivation systems. As shown in Fig. 1(c), when the waste nutrient solution was photocatalytically treated and silver-coated cloth was placed in the nutrient tank, the growth of bacteria in both the waste nutrient solution and in the rhizosphere of tomato roots was suppressed.
In our previous study, we have confirmed that TOC of the recycling nutrient solution using rice hull substrate was kept for 3 years at the low concentration by photocatalytic treatment in the actual tomato soilless cultivation system (Miyama et al., 2009). And, it is known that silver coated cloth can continue to release silver ion into the nutrient solution for half or one year. Therefore, it can be expected that the suppression effect on bacterial wilt disease in a laboratory scale (Fig. 3) is obtained even in the actual tomato soilless cultivation system over a long duration.

Although soil-borne plant diseases do not readily develop in soilless culture systems, the causal pathogens can be introduced when infected seedlings are planted in the cultivation field. Once disease occurs, the pathogens can rapidly spread, causing severe damage. Therefore, it is imperative that non-infected seedlings are grown in a greenhouse, and that the culture substrate, raw water, and nutrient solution are all disinfected prior to cultivation (Kita et al., 2003). In addition, any waste nutrient solution that will be recycled in closed soilless cultivation must also be disinfected (Vestergard, 1988). The disinfection methods of the waste nutrient solution, are treatments using ozone, hydrogen peroxide, and heating. However, the problems of the cost and risk remain for these methods. Our present findings suggest that the combined use of a temporary bactericide, such as the photocatalytic treatment of waste nutrient solution, with a continued bactericide such as silvercoated cloth added to the nutrient solution, is an effective approach for reducing the risk of soil-borne diseases in closed soilless cultivation. Moreover, such a strategy will minimize the energy costs associated with disinfection, because photocatalysis can be driven by sunlight. We therefore propose that the combination of photocatalytic treatment and silver-coated cloth will allow stable crop production in closed soilless cultivation systems and is compatible with environmental conservation agriculture.

In conclusion, $\mathrm{TiO}_{2}$ photocatalytic treatment for a simulated waste nutrient solution from closed soilless cultivation using rice hull substrate decreased the TOC concentration of the solution and enhanced the antibacterial activity of silver against wilt disease bacteria. The onset of wilt disease was also suppressed in tomato seedlings cultivated in the nutrient solution containing silver with photocatalytic treatment. Combining silver and photocatalytic treatments reduces the risk of soil-borne 
disease and achieves stable crop production, even in the context of closed soilless cultivation using an organic substrate.

The authors thank Mr. Greg Newton for the critical reading of this manuscript. This work was supported by a research grant for utilizing advanced technologies in agriculture, forestry, and fisheries from the Agriculture, Forestry and Fisheries Research Council, Japan.

\section{REFERENCES}

Fujishima, A., Hashimoto, K., Watanabe, T. 1999. $\mathrm{TiO}_{2}$ photocatalysis: Fundamentals and applications. BKC, Tokyo, pp 49-64.

Hashimoto, K., Irie, H., Fujishima, A. 2005. $\mathrm{TiO}_{2}$ photocatalysis: A historical overview and future prospects. Jpn. J. Appl. Phys. 44: 8269-8285.

Hayward, A. C. 1991. Biology and epidemiology of bacterial wilt caused by Pseudomonas Solanaserum. Ann. Rev. Phytopathol. 29: 65-87.

Herrmann, J. M. 1999. Heterogeneous photocatalysis: Fundamentals and applications to the removal of various types of aqueous pollutants. Catal. Today 53: 115-129.

Hoffmann, M. R., Martin, S. T., Choi, W., Bahnemann, D. W. 1995. Environmental applications of semiconductor photocatalysis. Chem. Rev. 95: 69-96.

Jenkins, S. F. J., Averre, C. W. 1983. Root diseases of vegetables in hydroponic culture systems in North Carolina greenhouses. Plant Dis. 67: 968-970.

Kita, N., Nishi, K., Uematsu, S. 2003. Hot water treatment as a promising alternative to methyl to methyl bromide. Annual International Research Conference on Methyl Bromide Alternatives and Emissions Reductions, November, Fresno, proceedings of $2003 \mathrm{p} 123.1-123.4$.

Kusakari, S., Egushi, S., Zho, Z., Sumi, T., Okada, K. 1998. Additive effects of silver-coated cloth in hydroponic solution in protection against Pythium root rot on cucumber and Japanese hornwort without residual silver in cucumber fruit. (in Japanese with English abstract) Ann. Phytopathol. Soc. Jpn. 64: 50-56.

Matsunaga, T., Tomoda, R., Nakajima, T., Wake, H. 1985. Photoelectrochemical sterilization of microbial-cells by semiconductor powders. FEMS Microbiol. Lett. 29: 211-214.

Miyama, Y., Sunada, K., Fujiwara, S., Hashimoto, K. 2009. Photocatalytic treatment of waste nutrient solution from soilless cultivation of tomatoes planted in rice hull substrate. Plant Soil. 318: 275-283.

Miyama, Y., Hara, Y., Hashimoto, K., Sunada, K. 2012. Closed soilless cultivation of roses planted in rice hull substrate with photocatalytic treatment of waste nutrient solution. (in Japanese with English abstract) J. SHITA 24: 31-37.

Noguchi, H., Nakajima, A., Watanabe, T., Hashimoto, K. 2003. Design of a photocatalyst for bromate decomposition: Surface modification of $\mathrm{TiO}_{2}$ by pseudo-boehmite. Environ. Sci. Technol. 37: 153-157.

Ohata, K., Araki, T., Kiso, A., Kudo, A., Takahashi, H. 1995. Methods for isolation, cultivation, inoculation of plant pathogens. Japan plant protection association, Tokyo, pp 272.

Ollis, D. F., Pelizetti, E., Serpone, N. 1991. Photocatalyzed destruction of water contaminants. Environ. Sci. Technol. 25: 1523-1529.

Pichat, P., Vannier, S., Dussand, J., Rubis, J. P. 2005. Assessment of solar photocatalysis to purify on site rinse waters from tractor cisterns used in grapevine pest control: Field experimentation. Water Sci. Technol. 52: 223-230.

Russell, A. D., Hugo, W. B. 1994. Antimicrobial activity and action of silver. Prog. Med. Chem. 31: 351-370.

Shinohara, Y., Hata, T., Maruo, T., Hohjo, M., Ito, T. 1999. Chemical and physical properties of the coconut-fiber substrate and the growth and productivity of tomato (Lycopersicon esculentum Mill.) plants. Acta Hort. 481: 145149.

Slade, S. J., Pegg, G. F. 1993. The effect of silver and other metal ions on the in vitro growth of root-rotting Phytophthora and other fungal species. Ann. Appl. Biol. 122: 233-251.

Stanghellini, M. E., Rasmussen, S. L. 1994. Hydroponics: A solution for zoosporic pathogens. Plant Disease 78: 1129-1137.

Sunada, K., Ding, X. G., Utami, M. S., Kawashima, Y., Miyama, Y., Hashimoto, K. 2008. Detoxification of phytotoxic compounds by $\mathrm{TiO}_{2}$ photocatalysis in a recycling hydroponic cultivation system of asparagus. J. Agric. Food Chem. 56: 48194824.

Sunada, K., Watanabe, T., Hashimoto, K. 2003. Studies on photokilling of bacteria on $\mathrm{TiO}_{2}$ thin film. J. Photochem. Photobiol. A: Chem. 156: 227-233.

Thurman, R. B., Gerba, C. P. 1989 . The molecular mechanisms of copper and silver ion disinfection of bacteria and viruses. CRC Crit. Rev. Environ. Microbiol. 18: 295-315.

Urrestarazu, M., Martínez, G. A., Salas, M. C. 2005. Almond shell waste: possible local rockwool substitute insoilless crop culture. Sci. Hort. 103: 453-460.

Van Os, E. A. 1994. Closed growing systems for more efficient and environmental friendly production. Acta Hort. 391: 194200.

Van Os, E. A. 1995. Engineering and environmental aspects of soilless growing systems. Acta Hort. 396: 25-32.

Van Os, E. A. 2000. New developments in recirculation systems and disinfection methods for greenhouse crops. The 15th Workshop on Agricultural Structures and ACESYS (Automation, Culture, Environment \& System). December, Tsukuba, abstract p81-91.

Vestergard, B. 1988. Sterilization of water and nutrient solutions. Acta Hort. 221: 303-313.

Zhao, Z., Kusakari, S., Okata, K., Miyazaki, A., Osaka, T. 2000. Control of Pythium root rot on hydroponically grown cucumbers with silver-coated cloth. Biosci. Biotechnol. Biochem. 64: $1515-1518$.

Zinnen, T. M. 1988. Assessment of plant diseases in hydroponic culture. Plant Disease 72: 96-99. 